Mini Review

\title{
Morphological and functional characteristics of models of experimental myocardial injury induced by isoproterenol
}

\author{
Zuzana Nichtova ${ }^{1,2}$, Marta Novotova ${ }^{1}$, Eva Kralova $^{2}$ and Tatiana Stankovicova ${ }^{2}$ \\ ${ }^{1}$ Institute of Molecular Physiology and Genetics, Slovak Academy of Sciences, Vlárska 5, 83334 Bratislava, Slovak Republic \\ ${ }^{2}$ Comenius University, Faculty of Pharmacy, Department of Pharmacology and Toxicology, Kalinčiakova 8, 83232 Bratislava, \\ Slovak Republic
}

\begin{abstract}
The animal models of myocardial injury induced by systemic $\beta$-adrenergic receptor agonist administration represent an experimental approach of persisting interest. These models were found useful especially for studies of structural and functional adaptation of myocardium during the progression of cardiac adaptive response towards maladaptive hypertrophy and insufficiency. The pathological alterations induced by isoproterenol (ISO) do not develop evenly. The ISO models may contribute effectively to understanding of pathologies in signal transduction, energetics, excitability and contractility that may contribute concomitantly to cardiac dysfunction and heart failure. In this minireview we focused on the alterations in general characteristics and heart function as well as on the morphological changes of cardiomyocytes developed during ISO administration. The morphological alterations within the cellular macro- and microdomains correspond to the electrical remodeling and contractile dysfunction of ventricular myocardium that could be used to identify pathological changes ranging from hypertrophy to failing heart.
\end{abstract}

Key words: Isoproterenol - Heart - Electrocardiogram - Hemodynamic - Ultrastructure

\section{Introduction}

Catecholamines increase the contractile force and the beating rate of the heart resulting in markedly increased cardiac pumping output and cardiac oxygen consumption, albeit at reduced efficiency. Excess of catecholamines in circulation is responsible for the myocardial tissue damage (Cibllis and Hirstat 1980) observed in clinical conditions such as ischemia, angina, infarction, cardiac arrhythmias and sudden cardiac death. Increased release of endogenous catecholamines as well as the increased administration of exogenous catecholamines leads to remodeling of myocardium and of cardiomyocytes at subcellular level (Raab 1960; Rona 1985). These effects of catecholamines were found useful for development of models of myocardial injury intended to study details of underlying processes at the tissue, cellular and molecular levels. Here we review

Correspondence to: Tatiana Stankovicova, Comenius University, Faculty of Pharmacy, Department of Pharmacology and Toxicology, Kalinčiakova 8, 83232 Bratislava, Slovak Republic

E-mail: stankovicova@fpharm.uniba.sk briefly the changes in the function and structure of hearts induced by administration of isoproterenol as reported up to date.

Cardiac remodeling resulting from increased heart rate and hemodynamic overload, or increased workload and increased wall tension (Lijnen et al. 2000; Ozaki et al. 2002) initiates cardiac hypertrophy as evidenced by both in vivo (Benjamin et al. 1989; Zierhut and Zimmer 1989; Boluyt et al. 1995) and in vitro (Clark et al. 1991; Zou et al. 1999) studies. Chronic stimulation of $\beta$-adrenergic receptor associated with cardiac overload and congestive heart failure (Bristow 2000) may cause progressive myocyte dysfunction, cell loss or cardiac chamber remodeling (Limbird and Voughan 1999) as it has been demonstrated in humans and experimental animals. Several mechanisms including increased preload and afterload, the defects in energy production and utilization, altered signal transduction, and calcium handling abnormalities have been put forward about the mechanism of induced cardiac injury (for review see Osadchii 2007; Dhalla et al. 2009).

Myocardial contractility is regulated by catecholamines through $\beta$-adrenergic receptors. Any alterations in the 
dynamics of $\beta$-adrenergic receptors would affect cardiac ourput. An externalization (overexpression) of $\beta$-adrenergic receptors contribute to the development of the hypercardiodynamic state, whereas an internalization (underexpression) of $\beta$-adrenergic receptors would lead to the formation of hypocardiodynamic state (Tang et al. 1998).

Administration of isoproterenol (ISO), a synthetic catecholamine, causes severe stress in the myocardium due to the activation of adrenergic system and other neurohumoral systems inducing an increase in the L-type $\mathrm{Ca}^{2+}$ channel activity. If the stress is sustained then the hearts are remodeled into a compensatory stage with enhanced contractility and sarcoplasmic reticulum $\mathrm{Ca}^{2+}$ load. During the progression of heart failure, the reduced or even compromised responsiveness to $\beta$-adrenergic stimulation was shown and excitation-contraction coupling efficiency was significantly reduced (Tang et al. 2010).

Stimulation of $\beta$-adrenergic receptors by ISO is associated with activation of the transduction mechanisms involving kinases, $\mathrm{G}$ proteins, and adenosine nucleotides (Zimmer 1997; Suzuki et al. 1998; Zou et al. 1999), activation of the renin - angiotensin - aldosterone system (Nagano et al. 1992; Golomb et al. 1994; Baillard et al. 2000; Leenen et al. 2001; Rajadurai and Prince 2007), induction of oxidative stress (Zhang et al 2005; Rajadurai and Prince 2007), activation of the $\mathrm{Na}^{+} / \mathrm{H}^{+}$exchanger (Ennis et al. 2003) and $\mathrm{Na}^{+} / \mathrm{Ca}^{2+}$ exchanger (Chorvatova et al. 2004), elevated levels of endothelins (Suzuki et al. 1998), or changes in NO production (Krenek et al. 2006, 2009; Ribeiro et al. 2009), increased expression of fibrogenic factors including, e.g., connective tissue growth factor (CTGF) and NADPH oxidase (NOX4) (Ma et al. 2011). Overexpression of $\beta_{1}$-adrenergic receptors and $\mathrm{G}_{\mathrm{s}}$-protein in the murine myocardium (Colluci et al. 2000) developed left ventricular dilatation, contractile dysfunction and apoptosis. However, downregulation of microRNA-133 is a prerequisite for the development of apoptosis, fibrosis, and prolongation of the QT interval (Abdellatif 2010).

In the earlier reports it was shown that repeated stimulation of $\beta$-adrenergic receptors by ISO did not extend necrotic lesions, but that the induced "myocardial resistance or adaptation" against ISO was developed (Poupa 1962; Turek et al. 1966; Korb and Totovič 1967; Moalic et al. 1993a). This finding is not clearly explained, however, it could be related to internalization or downregulation of $\beta$-adrenergic receptor.

Downregulation of $\beta$-adrenergic receptor signaling pathway is manifested as reduced $\beta$-adrenergic receptor density and impaired transduction pathways and has been linked to increased left ventricular tissue mass in hypertrophied rat hearts (Moalic et al. 1993b), or as an important attribute of human heart failure (Fowler et al. 1986). However, Sethi et al. (2007) demonstrated that $\beta$-adrenergic receptor-mediated signal transduction mechanism is unaltered or upregulated in the compensated stages of cardiac hypertrophy and are downregulated in the decompensated stages of cardiac hypertrophy.

Recently, Soltysinska et al. (2011a) provided experimental evidence, that sustained sympathetic activation by very low dose of isoproterenol infusion $(400 \mu \mathrm{g} / \mathrm{kg} \cdot \mathrm{h}$ over 16 days) may promote downregulation of myocardial $\beta$-adrenergic receptor-mediated effects associated with markedly reduced $\mathrm{G}_{\mathrm{s} \alpha}$-protein expression. These changes could represent an early negative feedback to enhanced adrenergic tone.

\section{ISO-induced myocardial injury}

Adrenergic over-activation promoted development of cardiac hypertrophy. Despite the positive inotropic and chronotropic effect on the heart, administration of ISO decreases peripheral resistance and produces vasodilatation in many vascular beds that results in reduced diastolic and systolic blood pressure (Lijnen et al. 2000; Ozaki et al. 2002; Rajadurai and Prince 2007). Recent clinical study showed (Strand et al. 2006) that development of cardiac hypertrophy is independent of systolic blood pressure (Verdecchia et al. 1998; Mathew et al. 2001). Therefore the important role of sustained adrenergic receptor activation in association to cardiac hypertrophy and failure was suggested. Acute ISO administration produced tachycardia associated with relative ischemia due to imbalance between increased myocardial oxygen demand and reduced coronary blood supply. The increased demands placed on the heart lead to an increased heart/body weight ratio as a result of the increased afterload or direct $\beta$-adrenergic receptor stimulation (Dresel et al. 1963; Lijnen et al. 2000; Ozaki 2002).

$\beta$-adrenergic receptors stimulation by ISO for more than 3 days resulted in cardiac hypertrophy demonstrating as an increased ratio of heart weight to body weight (Zimmer 1997; Linck et al. 1998; Suzuki et al. 1998). Seven days lasting ISO treatment $(2 \mathrm{mg} / \mathrm{kg})$ induced hypertrophy of the left ventricle (Fereira 2007). Nagano et al. (1992) reported that ISO application for 7 days increased both the left and the right ventricular weight. Krenek et al. (2009) found an increased weight of both chambers and atria upon low-dose administration of ISO (5 mg/kg, 7 days). Similar results reported by Leenen et al. (2001) indicated a significant increase in the weight and thickness of the right and left ventricles and typical increase in thickness of the septum. Comparison between the two weeks lasting daily subcutaneous injection or continuous infusion of ISO revealed similar degree of cardiac hypertrophy in mice. However, daily injection developed more severe ventricular systolic and diastolic 
dysfunction and myocardial fibrosis than sustained exposure to a $\beta$-adrenergic receptor agonist (Ma et al. 2011). In rats, prolongation of the low-dose ISO stimulation led to appearance of infarct-like necrotic regions, resembling myocardial infarction in humans (Rona et al. 1959; Kahn et al. 1969; Benjamin et al. 1989; Teerlink et al. 1994), and to congestive heart failure (Armoundas et al. 2001; Bénitah 2002; Ennis et al. 2003).

Chronic ISO administration of very low doses $(400 \mu \mathrm{g} /$ $\mathrm{kg}$.h over 16 days) to guinea pig did not produce left ventricular hypertrophy and the dilatation and left ventricular systolic functions were well preserved. No differences in the epicardial action potential duration and the effective refractory period were detected. In contrast to downregulation of $\beta$-adrenergic receptor-mediated pharmacological responses, the left ventricular hypertrophy contractile and electrophysiological responses induced by forskolin stayed well preserved indicating development of independent pathways for $\beta$-adrenergic receptor downregulation and for heart remodeling and systolic failure (Soltysinska et al. 2011a).

Different single or repeated doses of ISO administered to experimental animals induced not only different degrees of apoptotic, regressive or degenerative processes in myocardium but allowed also the studies of reparative processes in ISO damaged myocardium leading to improved cardiac function (Ellison et al. 2007; Angert et al. 2011).

\section{Classification of ISO effects}

Based on the available literature the ISO-induced effects on heart could be divided into 3 groups depending on the dose and duration of ISO administration:

- low doses of isoproterenol (0.3-6 mg/kg body weight) administered acutely or repeatedly during 1-3 weeks

- medium doses of isoproterenol (10-85 mg/kg body weight) applied in a single dose

- high doses of isoproterenol (150-300 mg/kg body weight) applied in a single dose or in two consecutive doses.

\section{Low-dose ISO models}

Very low doses of ISO, $0.3 \mathrm{mg} / \mathrm{kg}$, applied for 7 days did not affect the blood pressure in rats (Lijnen et al. 2000). However, it was shown, that low doses of ISO $(0.3$ to $6 \mathrm{mg} / \mathrm{kg})$ induce cardiac hypertrophy accompanied by fibrosis and necrosis of the tissue (Rona et al. 1961, Meszaros and Levai 1990; Nagano et al. 1992; Meszaros and Pasztor 1995; Zimmer 1997; Suzuki et al. 1998; Lijnen et al. 2000; Meszaros et al. 2001; Ocaranza et al. 2002; Sia et al. 2002; Goldspink et al. 2004; Zhang et al. 2007). At the level of cardiac myocytes, the signs of apoptosis were observed that appeared within
3-6 hours after single ISO application (Goldspink et al. 2004; Krenek et al. 2009). The apoptosis and continuing loss of viable myocytes could be a mechanism for progressive myocardial failure (Colluci et al. 2000).

Meszaros and Levai (1990) described electrical properties of cardiac cells. They characterized three basic types of cells present in the myocardium after 7 days lasting administration of $5 \mathrm{mg} / \mathrm{kg} /$ day of ISO:

- healthy cells with normal action potentials

- physiological hypertrophied cells with prolonged action potential

- pathological hypertrophied cells with very short action potentials.

In the model of ISO-induced myocardial hypertrophy (5 mg/kg/7 days) Krenek et al. (2009) found ST segment depression and negative $\mathrm{T}$ wave, which point to the presence of myocardial ischemia. In the same model, Kralova et al. (2008) and Mikusova et al. (2009) analyzed electrocardiograms (ECG) of anesthetized rats and of isolated hearts (Fig. 1). They revealed typical ECG characteristics of hypertrophy in ISO-treated hearts, specifically, the longer duration of QT interval and of QRS complex, the negative Q and S waves, flattening and lengthening of $\mathrm{T}$ wave, higher $\mathrm{R}$ amplitude and increased values of voltage criteria, namely, of the Lewis, Sokolow-Lyon, and Cornell indexes. Hypertrophic changes predisposed the hearts to higher incidence of ventricular ectopic activity, as well as episodes of non-sustained ventricular tachycardia and fibrillation. The slowed left ventricular contractile performance and impaired perfusion of coronary vessels were observed after ISO treatment.

Repeated administration of ISO at low doses $(5 \mathrm{mg} / \mathrm{kg}$ i.p. daily) for 1-3 weeks led to gradual development of myocardial necrosis (Meszaros and Levai 1990). A less than 7 days ISO treatment induced the early stage of hypertrophy characterized by a few and small necrotic foci. At the level of cardiomyocytes, the aggregation and swelling of mitochondria was described. This stage is known as the compensated or so called physiological hypertrophy. The prolonged ISO treatment induced the late stages of hypertrophy characterized by a pathological hypertrophy with massive confluent myocardial lesions. In cardiomyocytes, the myofibrils were enlarged; mitochondria were massively swollen with disrupted cristae and outer membranes.

An electron microscopic study aimed at changes in cellular organization during development of the compensated hypertrophy (Mikusova et al. 2009) characterized subcellular remodeling in the functional myocardium (Fig. 2). The adaptive changes of cardiomyocytes occurred mainly in the plasma membrane, showing increased incidence of caveolae and increased vesiculation of t-tubules, especially near the dyads. This study also revealed fully differentiated myocytes showing small regions with morphological features of postnatal cardiomyocytes. 
Low-dose ISO-induced hypertrophy ceases rapidly after termination of ISO administration (Golomb et al. 1994). Tang and Taylor (1984) described attenuation of hypertrophy over 4 days after the last ISO application. Ocaranza et al. (2002) reported that there was spontaneous regression of the left ventricular hypertrophy but no regression of fibrosis on days 15 and 33 after the last application of ISO $(5 \mathrm{mg} / \mathrm{kg}$ for 10 days).
A

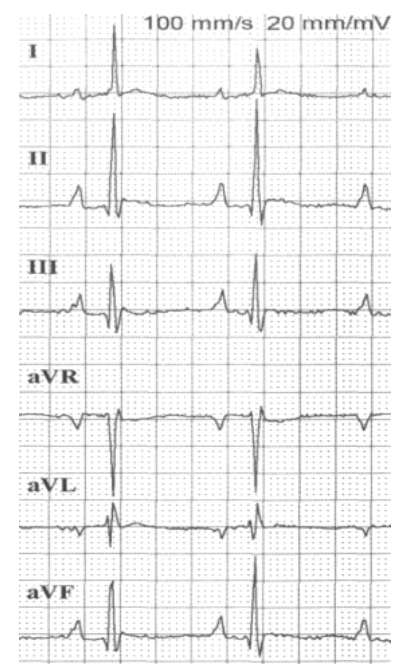

B

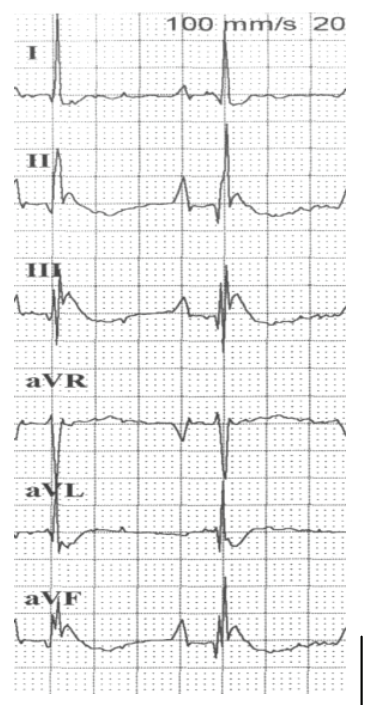

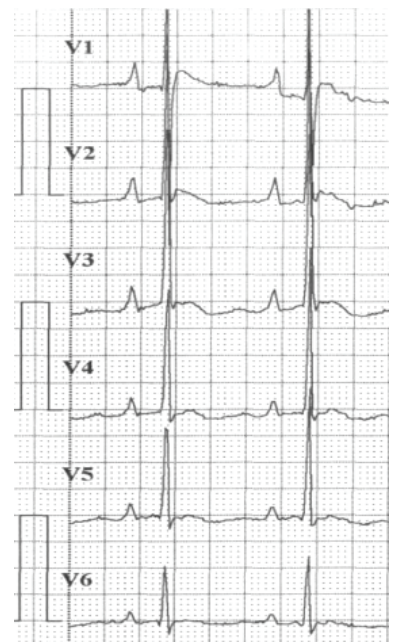

Control: rat (Wistar CIII/6)

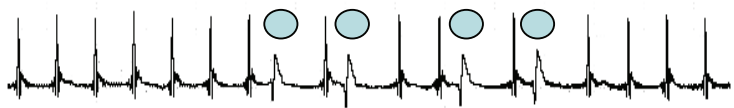

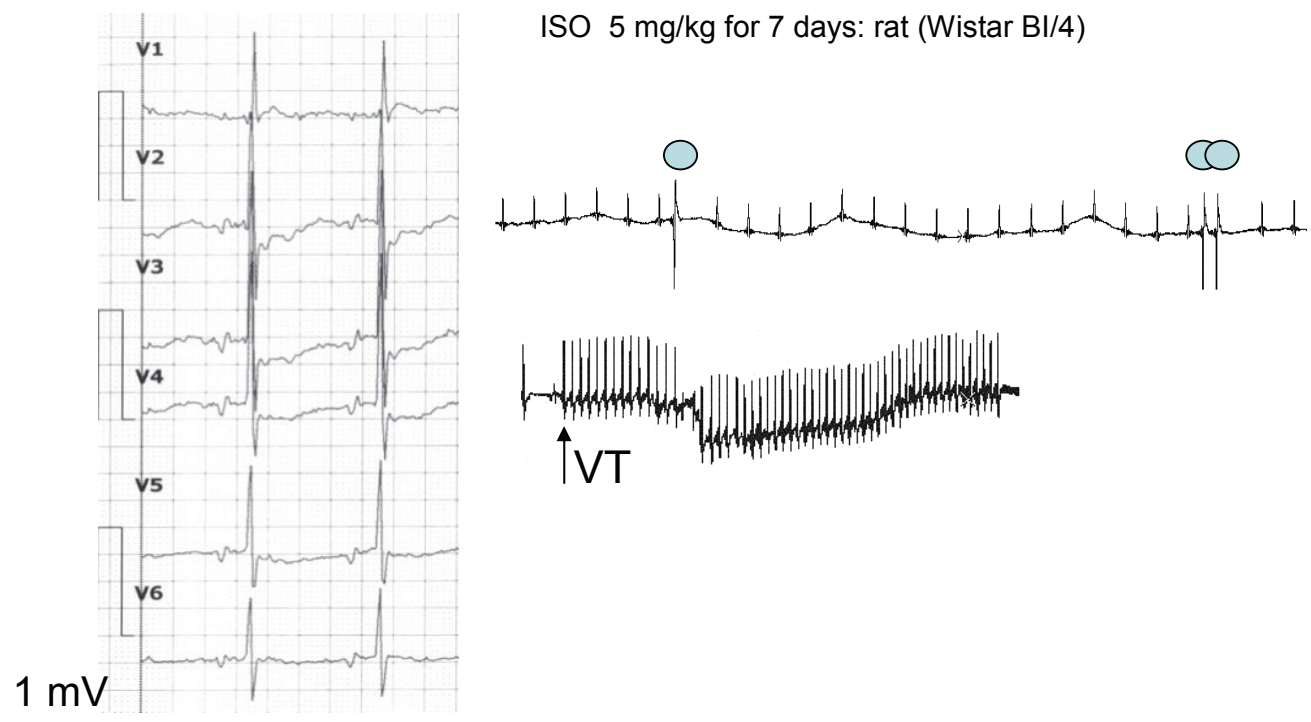

\section{$0,6 \mathrm{~ms}$}

Figure 1. Typical 12 lead surface ECG and bipolar left ventricular ECG of rat. A. Control ECG recorded on day 7 after daily s.c administration of the vehicle. Characteristics of the control ECG (left): heart rate 333 beats/min, R amplitude higher in II. limb lead, T wave positive, negative $S$ wave. Characteristics of the bipolar left ventricular ECG of the isolated spontaneously beating control rat heart (right): heart rate 220 beats/min, regular, occasionally incidence of ventricular premature beats (filled dots), T wave positive. B. ECG recorded on day 7 after daily s.c administration of $5 \mathrm{mg} / \mathrm{kg}$ isoproterenol (ISO). Characteristics of the ISO-treated rat ECG (left): variable size of $\mathrm{R}$ amplitude, enlargement of $\mathrm{R}$ wave amplitude in the I. limb lead, lengthening of QRS complex, negative $\mathrm{Q}$ wave, negative $\mathrm{T}$ wave in the limb and chest leads, ST segment depression, prolongation of QT interval. Characteristics of the bipolar left ventricular ECG of the spontaneously beating heart isolated from ISO-treated rat (right): slower heart rate, increased amplitude of R wave, presence of different forms of ventricular premature beats (filled dots), episodes of ventricular tachycardia (VT). 

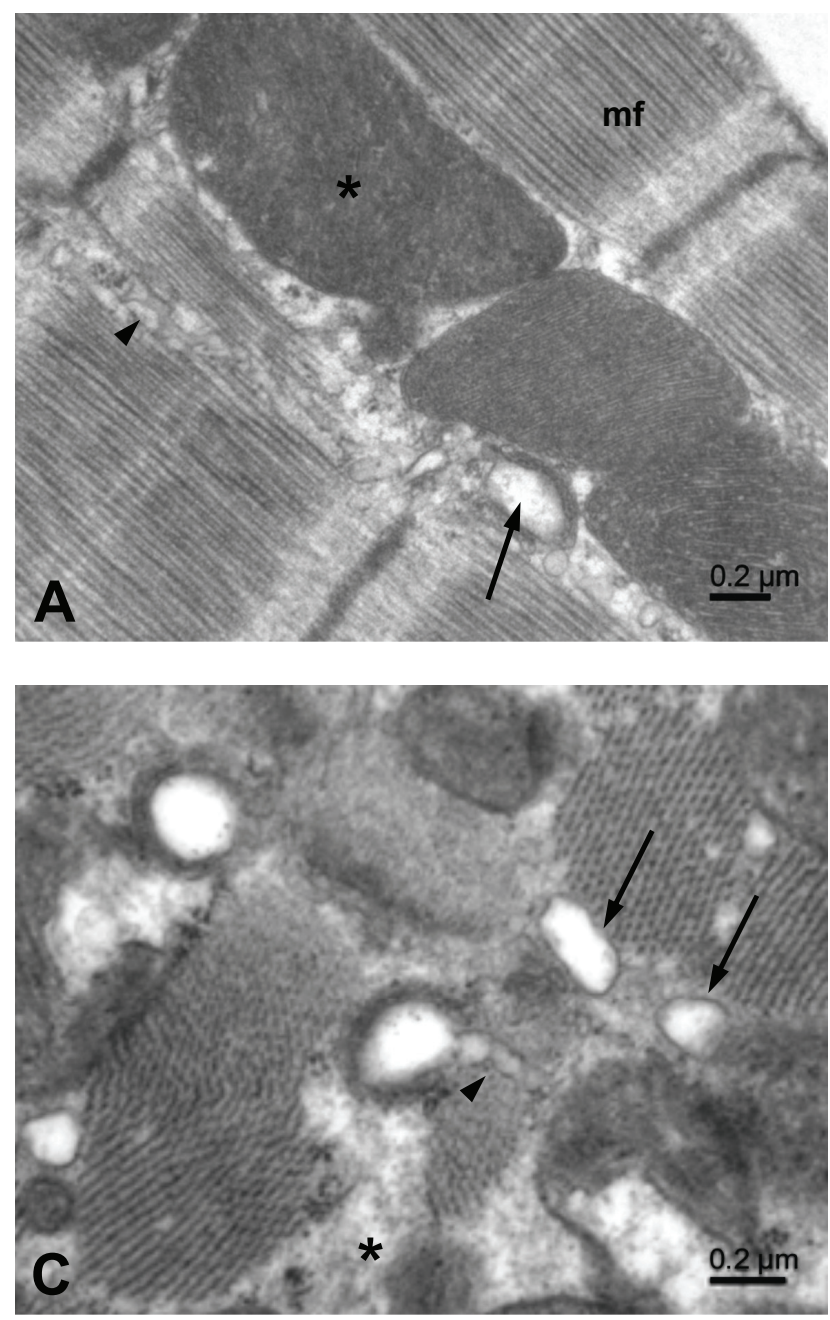

In the late stage of hypertrophy induced by a prolonged treatment by the low dose of ISO ( $5 \mathrm{mg} / \mathrm{kg}$ for 21 days), the cardiac overload issued in the myocardial failure and leads to increased incidence of death up to $80-90 \%$ (Meszaros and Levai 1990; Kralova et al. 2009). In surviving animals, the ventricular function is aggravated in comparison to that observed after 7 days of ISO administration. The increased left ventricular weight and the thickness of the free wall, increased internal diameter of the left ventricular cavity together with markedly reduced contractility, increased diastolic pressure and lower coronary perfusion. At the same time, ECG display longer duration of waves and QRS complex, prolongation of PQ and QT intervals, decreased R amplitude, lowered voltage criteria and suppressed dysrhythmic activity that characterize progression of the myocardial hypertrophy towards failing heart (Kralova et al. 2009; Nichtova et al. 2010). Soltysinska et al. (2011b) found that lengthening of QT interval as well as epicardial action potential prolongation are associated with progression of heart failure in ani-

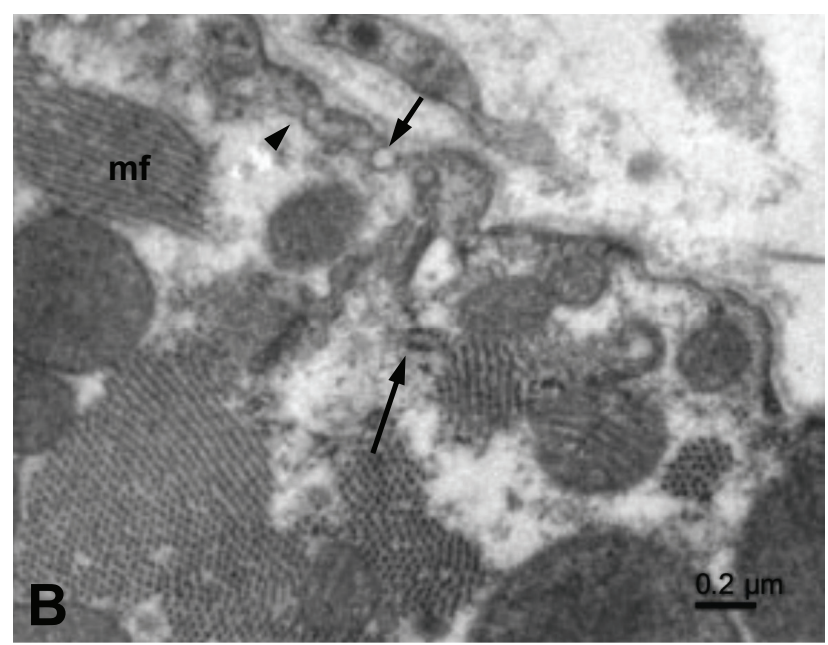

Figure 2. Electron micrographs of the left ventricular myocytes of the control rat heart and the rat heart treated with the low dose of isoproterenol (ISO; $5 \mathrm{mg} / \mathrm{kg}$ s.c. for 7 days). A. Control rat cardiomyocyte showing densely packed myofibrils ( $\mathrm{mf})$, mitochondria $\left.{ }^{*}\right)$, membrane system of sarcoplasmic reticulum (arrowhead) and dyad (arrow), with very low content of the free cytoplasm. B. ISO rat cardiomyocyte showing hypertrophying area under the plasma membrane. The cytoplasm contains clusters of ribosomes (arrow) and disorganized myofibrils (mf). The plasma membrane covered with the basement membrane forms caveolae (short arrow) and vesicles (arrowhead). C. ISO rat cardiomyocyte showing the hypertrophying area in the intermyofibrillar space. The myofibrils and the t-tubules (arrows) are not well organized. The increased content of free cytoplasm ${ }^{*}$ ) and deformation of t-tubule near the dyadic microdomain (arrowhead) is observed.

mals exposed to daily ISO $1 \mathrm{mg} / \mathrm{kg}$ addition over 3 months. Electrical remodeling of hypertrophic myocardium could be induced either by low doses of ISO for 1-3 weeks, or by very low ISO doses but for longer time period.

Electron microscopic analysis of surviving cardiomyocytes in the late stage hypertrophy (Nichtova et al. 2010) showed increased number of newly formed sarcoplasmic processes containing disorganized masses of myofibrils without t-tubules and sarcoplasmic reticulum. A part of the cardiomyocyte ultrastructure did not differ markedly from controls. In mice, the similar experiments (ISO $6 \mathrm{mg} / \mathrm{kg}$, 21 days) showed developing cardiac hypertrophy, which, however, exhibited preserved t-tubule system (Horiuchi-Hirose et al. 2010).

\section{Medium-dose ISO models}

Two-days lasting administration of increased ISO dose (40 mg/kg body weight) led to a significant but temporary 
reduction in systolic and diastolic blood pressure, however, prolonged administration of ISO did not affect blood pressure (Leenen et al. 2001; Zhang et al. 2005).

The medium doses of ISO $(10-85 \mathrm{mg} / \mathrm{kg})$ induced structural changes of mitochondria that are characterized by swelling, by decreased amount of cristae and increased presence of the homogenized matrix in mitochondrial population (Chagoya de Sanchez et al. 1997; Dudnáková et al. 2003; Rajadurai and Prince 2007). These doses of ISO led to dilatation of tubules of the sarcoplasmic reticulum and to occurrence of vacuolae, originating probably from the sarcoplasmic reticulum.

Applications of medium doses of ISO to rats $(65 \mathrm{mg} / \mathrm{kg}$, Chagoya de Sanchez et al. 1997) induced myocardial damages in left ventricles (especially near the apex) similar to infarct-like areas as observed 12 to 24 hours after the ISO application. The heart rate increased by about $60 \%$ in about 3 minutes after ISO administration. Additionally, shortening of the atrioventricular interval, decrease of systemic blood pressure and decrease of left ventricular pressure were observed. Five hours after ISO administration, decreased levels of the mitochondrial oxygen consumption, of the respiratory quotient, of ATP synthesis, as well as of the membrane potential were observed. These results revealed that the application of medium doses of ISO leads to changes in energy metabolism in cardiomyocytes.

\section{High-dose ISO models}

It was shown that high doses of ISO, within the $85-300 \mathrm{mg} / \mathrm{kg}$ range, induced diffuse myocardial necrosis and ultimately lead to progressive left ventricular dilatation and myocardial hypertrophy (Rona et al. 1959; Kahn et al. 1969; Benjamin et al. 1989; Teerlink et al. 1994; Ribeiro et al. 2009). The high dose of ISO induced in rat heart similar myocardial damage as acute myocardial infarction. This finding suggested that high dose of ISO could be used as a model of heart failure induced by acute myocardial infarction (Feng and Li 2009). The same authors concluded that ISO administered at 85/340 $\mathrm{mg} / \mathrm{kg}$ on two consecutive days induced heart failure 4 -weeks follow-up.

Single dose of $150 \mathrm{mg} / \mathrm{kg}$ ISO induced necrotic changes in rat cardiomyocytes within 24 hours. On the tissue level they manifested as dilatation of intercellular space and increased fibrosis (Grimm et al. 1998). Pick et al. (1989) reported that high doses of ISO cause significant alterations in the meshwork of thick and thin collagen fibers. The increased expression of extracellular matrix proteins (fibronectin and collagen) could play an important role by maintaining the structural integrity of the myocardium. However, it could contribute to the reduced tissue plasticity and the related systolic and diastolic dysfunction of myocardium (Grimm et al. 1998).

Bestetti et al. $(1987,1990)$ described changes in ECG on day 10 after two doses of ISO (200 mg/kg body weight). They showed pathological Q waves, lengthening of the QRS complex and QRS abnormalities, and increased PR and QT intervals. Moreover, they identified apical aneurysm of the left ventricle and multifocal disseminated microscopic cardiac lesions. Administration of a single 150 $\mathrm{mg} / \mathrm{kg}$ ISO dose to rats (Kralova et al. 2008) increased the left ventricular weight/body weight index, decreased the thickness of the interventricular septum and of the free wall, diminished myocardial contractility, and increased incidence of the ventricular premature beats above that caused by application of $5 \mathrm{mg} / \mathrm{kg}$ ISO for 7 days. The changes in electrocardiograms corresponded to changes reported in post-infarcted hypertrophic failing heart with ischemic-necrotic lesions.

In rat hearts, administration of a single high dose of ISO leads to formation of infarcted regions containing necrotic tissue in the ventro-lateral part of the left ventricular free wall above the apex. Electron microscopic study of myocardium outside of the necrotic regions that developed on day 14 after single dose of $150 \mathrm{mg} / \mathrm{kg}$ ISO (Novotova et al. 2006) revealed ultrastructural changes in cardiomyocytes at the level of myofibrils, mitochondrial populations and the t-system tubules. In the mid-and endocardial myocytes of the left ventricles, as well as in myocytes of papillary muscles, the t-tubules and the longitudinal sarcoplasmic reticulum were vesiculated. The mitochondrial changes were apparent especialy in myocytes of the papillary muscle, where ultrastructural disturbances could be observed also at the level of myofibrils. Cardiomyocytes outside the necrotic region displayed subcellular heterogeneities and alterations in the membrane system of the dyadic junctions, which represent morphological substrate of excitation-contraction coupling (ECC). Changes in the microarchitecture of dyads could in part cause disturbance of ECC (Cannell et al. 1995; Lopez-Lopez et al. 1995; Cannell et al. 2006; Song et al. 2006; Crossman et al. 2011) and consequently affect contraction of myocytes. Gomez et al. (2001) and Houser (2001) considered contribution of morphological changes in dyadic microdomains to disturbances of calcium signaling in cardiomyocytes isolated from failing hearts. This was supported recently by mathematical model about whole-cell response of cardiomyocytes after $\beta$-adrenergic receptor stimulation (Heijman et al. 2011). The model built on the known compartmental interactions explained the contribution of local signaling domains to cell electrophysiology and calcium signaling during $\beta$-adrenergic receptor stimulation and provides a basis for studies on their role under pathological conditions. 


\section{Conclusion}

ISO-induced myocardial injury manifests clearly in the whole body as well as in isolated heart myocardium electrocardiograms and in the function and ultrastructure of cardiomyocytes. The observed macroscopic and microscopic tissue heterogeneities contribute to the pathological alterations of the electrophysiological and contractile properties of the myocardium. The described changes develop proportionally to the dose and the duration of ISO administration and can be adjusted to induce required degree of pathology from mild hypertrophy up to congestive heart failure.

ISO-induced myocardial hypertrophy is demonstrated not only by the increased heart weight to body weight index, but also by the increased amplitude of $\mathrm{R}$ wave and other voltage criteria. The $\mathrm{R}$ wave amplitude decrease in the II. limb lead but its increase in the I. limb lead is a marker of the left ventricular hypertrophy (Kannel 1998). The increased mass of hearts was confirmed by the higher amplitude of the $\mathrm{R}$ wave recorded from the perfused hearts isolated from the rats previously used for body ECG (Kralova et al. 2008; Mikusova et al. 2009). In clinical studies, the ventricular hypertrophy was characterized by increased voltage criteria (Okin et al. 2003, 2004; Oikarinen et al. 2004) and correlates well with the results of Kralova et al. (2008) who showed increased voltage criteria in rats with ISO-induced ventricular hypertrophy.

It seems worthwhile, that the ISO-increased workload of the heart and imbalance between the blood supply and tissue oxygen demands are important factors in the development of myocardial ischemia and necrosis and from the structural point of view are hardly distinguished from the ischemia induced by coronary occlusion. However, the deepened S wave and ascending depression of ST segment could indicate an increased tonus of sympathetic nervous system.

Prolonged QRS duration is frequently observed in patients with congestive heart failure (Dhingra et al. 2006) and is consistent with the hypothesis that depolarization delay may increase the risk of congestive heart failure. Pathological changes in the ST segment, $\mathrm{T}$ wave, and Q wave morphology indicate ischemic process developed within the layers of myocardium (Khan 2003).

Electrocardiographic abnormalities were described in all ISO-treated animals. In the majority of reports, prolongations of the PQ and QT intervals, QRS complex were found. Lengthening of the above mentioned parameters associated with slower spreading of electrical impulses throughout the myocardium, resulted from the interstitial tissue reaction as well as from the structural changes in cardiomyocytes (Haunstetter and Izumo 2000; Swynghedauw 2005). Increased duration of QT interval is suggested as a risk factor for higher myocardial susceptibility to arrhythmias. How- ever, QT interval prolongation with simultaneous decrease in the incidence of ventricular ectopic beats and of ventricular tachycardia could suggest the transition from the myocardial hypertrophy to heart failure.

ISO models of myocardial injury allowed revealing ultrastructural changes at the level of cardiac myocytes and their sarcolemmal, contractile, mitochondrial, and dyadic microdomains. Morphological alterations of sarcolemma and submembrane regions, of the membranes of $\mathrm{t}$-tubules and of sarcoplasmic reticulum, of the myofibrils and mitochondria are likely to be associated with the modifications in signaling cascades involved in calcium signaling, contractility and energetics at the cellular level that can reach as far as to the abnormalities in the electrical activity, contractility and energetics at the organ levels. Understanding remodeling at the level of microdomains is the next step in understanding of the complexity of interactions between the morphological substrates and cardiac function observed during myocardial hypertrophy and transition to heart failure.

\section{Brief completing of relations to clinics}

Experimental animal models based on administration of ISO allow insights into the pathomechanisms and pathological abnormalitites developed under $\beta$-adrenergic receptor stimulation and help to find optimal approach to therapy of sympathetic overactivation induced effects.

In vitro and in vivo observations provide a rational mechanism by which $\beta$-adrenergic receptor overstimulation induced left ventricular remodeling and heart failure in patients (Collucci et al. 2000). However, clinical signs of congestive heart failure were evident only in animals subjected to volume overload (Sethi et al. 2007) but not to pressure overload.

Acute $\beta$-adrenergic receptor agonist ISO administration induces myocardial ischemia as was shown in the surface ECG of patients next to circulatory support after cardiac surgery (Bestetti et al. 1987). Single or two ISO overdoses induced in rat heart similar signs of acute myocardial infarction as in humans, therefore the ISO model is used as a non-invasive AMI model with HF (Chagoya de Sanchez et al. 1997).

The acute stress induced increase in the cardiac activity followed by imbalance between blood supply and tissue demands resulted in the ischemic-necrotic tissue injury, arrhythmogenesis and even an acute unexpected death and increased mortality both in animals and patients (Landmesser and Drexler 2007). However, if the stress is sustained then the heart is subjected to remodeling toward the heart failure at the organ, myocyte, and molecular levels. Sympathetic nervous system activity to the myocardium is increased in the patients with heart failure. 
Acknowledgements. We thank Dr. Ivan Zahradník and Dr. Peter Krenek for the criticisms and helpful discussions of the manuscript. The work was supported in part by grants VEGA SR 1/4244/07, 2/0174/09, 1/0726/10, 2/0116/12, 1/1342/12 SR APVV 51-059-505 APVV-0139-06, APVV-0721-10 and European Union Contract No. LSHM-CT-2005-018833/EU GeneHeart.

\section{References}

Abdellatif M. (2010): The role of microRNA-133 in cardiac hypertrophy uncovered. Circ. Res. 106, 16-18 http://dx.doi.org/10.1161/CIRCRESAHA.109.212183

Angert D., Beretta R. M., Kubo H., Zhang H., Chen X., Wang W., Ogorek B., Barbe M., Houser S. R. (2011): Repair of the injured adult heart involves new myocytes potentially derived from resident cardiac stem cells. Circ. Res. 108, 1226-1237 http://dx.doi.org/10.1161/CIRCRESAHA.110.239046

Armoundas A. A., Wu R., Juang G., Marban E., Tomaselli G. F. (2001): Electrical and structural remodeling of the failing ventricle. Pharmacol. Ther. 92, 213-230 http://dx.doi.org/10.1016/S0163-7258(01)00171-1

Baillard C., Mansier P., Ennezat P. V., Mangin L., Medigue C., Swynghedauw B., Chevalier B. (2000): Converting enzyme inhibition normalizes QT interval in spontaneously hypertensive rats. Hypertension 36, 350-354

Bénitah J. P. (2002): Altered communication between L-type calcium channels and ryanodine receptors in heart failure. Fron. Biosi. 7, 263-275

Benjamin I. J., Jalil J. E., Tan L. B., Cho K., Weber K. T., Clark W. A. (1989): Isoproterenol-induced myocardial fibrosis in relation to myocyte. Circ. Res. 65, 657-670

Bestetti R. B., Ramos C. P., Figuerêdo-Silva J., Sales-Neto V. N., Oliveira J. S. (1987): Ability of the electrocardiogram to detect myocardial lesions in isoproterenol induced rat cardiomyopathy. Cardiovasc. Res. 21, 916-921 http://dx.doi.org/10.1093/cvr/21.12.916

Bestetti R. B., Oliveira J. S. (1990): The surface electrocardiogram: a simple reliable method for detecting overt and latent hearts disease in rats. Braz. J. Med. Biol. 23, 1213-1222

Boluyt M. O., Long X., Eschenhagen T., Mende U., Schmitz W., Crow M. T., Lakatta E. G. (1995): Isoproterenol infusion induces alterations in expression of hypertrophy-associated genes in rat heart. Am. J. Physiol. 269, H638-647

Bristow M. R. (2000): Beta adrenerenergic receptor blockade in chronic heart failure. Circulation 101, 558-569

Cannell M. B., Cheng H., Lederer W. J. (1995): The control of calcium repase in heart muscle. Science 268, 1045-1049 http://dx.doi.org/10.1126/science.7754384

Cannell M. B., Crossman D. J., Soeller C. (2006): Effect of changes in action potential spike configuration, junctional sarcoplasmic reticulum micro-architecture and altered t-tubule structure in human heart failure. J. Muscle Res. Cell. Motility 27, 297-306 http://dx.doi.org/10.1007/s10974-006-9089-y

Chagoya de Sánchez V., Hernández-Muňoz R., López-Barrera F., Yaňez L., Vidrio S., Suárez J., Cota-Garza M. D., ArandaFraustro A., Cruz D. (1997): Sequential changes of energy me- tabolism and mitochondrial function in myocardial infarction induced by isoproterenol in rats: a long-term and integrative study. Can. J. Physiol. Pharmacol. 75, 1300-1311

http://dx.doi.org/10.1139/y97-154

Chorvatova A., Hart G., Hussain M. (2004): $\mathrm{Na}+\mathrm{Ca} 2+$ exchange current $(\mathrm{I}(\mathrm{Na} / \mathrm{Ca}))$ and sarcoplasmic reticulum $\mathrm{Ca} 2+$ release in catecholamine-induced cardiac hypertrophy. Cardiovasc. Res. 61, 278-287 http://dx.doi.org/10.1016/j.cardiores.2003.11.019

Cibllis M. S., Hirstat C. S. (1980): Human stress cardiomyopathy. Human Pathol. 11, 123-132 http://dx.doi.org/10.1016/S0046-8177(80)80129-8

Clark W. A., Rudnick S. J., LaPres J. J., Lesch M., Decker R. S. (1991): Hypertrophy of isolated adult feline heart cells following betaadrenergic-induced beating. Am. J. Physiol. 261, C530-542

Colucci W. S., Sawyer D. B., Singh K., Communal C. (2000): Adrenergic overload and apoptosis in heart failure: implications for therapy. J. Card. Fail. 2, 1-7

Crossman D. J., Ruygrok P. N., Soeller C., Cannell M. B. (2011): Changes in the organization of excitation-contraction coupling structures in failing human heart. PLoS One 6, el7901 http://dx.doi.org/10.1371/journal.pone.0017901

Dhalla N. S., Saini-Chohan H. K., Rodriguez-Leyva D., Elimban V., Dent M. R., Tappia P. S. (2009): Subcellular remodelling may induce cardiac dysfunction in congestive heart failure. Cardiovasc. Res. 81, 429-438 http://dx.doi.org/10.1093/cvr/cvn281

Dhingra R., Pencina M. J., Wang T. J., Nam B. H., Benjamin E. J., Levy D., Larson M. G., Kannel W. B., D'Agostino R. B. Sr, Vasan R. S. (2006): Electrocardiographic QRS duration and the risk of congestive heart failure: the Framingham Heart Study. Hypertension 47, 861-867 http://dx.doi.org/10.1161/01.HYP.0000217141.20163.23

Dresel P. E., Hart M. C., Strömbland B. C. R. (1963): Cardiac arrhythmias induced by injection of isoproterenol into the coronary arteries. J. Pharmacol. Exp. Ther. 140, 67-75

Dudnáková T. V., Lakomkin V. L., Tsyplenkova V. G., Shekhonin B. V., Shirinsky V. P., Kapelko V. I. (2003): Alterations in myocardial ultrastructure and protein expression after a single injection of isoproterenol. Mol. Cell. Biochem. 252, 173-181 http://dx.doi.org/10.1023/A:1025579624695

Ellison G. M., Torella D., Karakikes I., Purushothaman S., Curcio A., Gasparri C., Indolfi C., Cable N. T., Goldspink D. F., Nadal-Ginard B. (2007): Acute $\beta$-adrenergic overload produces myocyte damage through calcium leakage from ryanodine receptor 2 but spares cardiac stem cells. J. Biol. Chem. 282, 11397-11409 http://dx.doi.org/10.1074/jbc.M607391200

Ennis I. L., Escuredo E. M., Console G. M., Camihort G., Dumm C. G., Seidler R. W., Camilión de Hurtado M. C., Cingolani H. E. (2003): Regression of isoproterenol-induced cardiac hypertrophy by $\mathrm{Na}+/ \mathrm{H}+$ exchanger inhibition. Hypertension 41, 1324-1329 http://dx.doi.org/10.1161/01.HYP.0000071180.12012.6E

Feng W., Li W. (2009): The study of ISO induced heart failure rat model. Exp. Mol. Pathol. 88, 299-304 http://dx.doi.org/10.1016/j.yexmp.2009.10.011

Ferreira A. J., Oliveira T. L., Castro M. C., Almeida A. P., Castro C. H., Caliari M. V., Gava E., Kitten G. T., Santos R. A. (2007): 
Isoproterenol-induced impairment of heart function and remodeling are attenuated by the nonpeptide angiotensin-(1-7) analogue AVE 0991. Life Sci. 81, 916-923 http://dx.doi.org/10.1016/j.lfs.2007.07.022

Fowler M. B., Laser J. A., Hopkins G. L., Minobe W., Bristow MR. (1986): Assessment of the beta-adrenergic receptor pathway in the intact failing human heart: progressive receptor downregulation and subsensitivity to agonist response. Circulation 74, 1290-1302 http://dx.doi.org/10.1161/01.CIR.74.6.1290

Goldspink D. E., Burniston J. G., Ellison G. M., Clark W. A., Tan L. B. (2004): Catecholamine-induced apoptosis and necrosis in cardiac and skeletal myocytes of the rat in vivo: the same or separate death pathways? Exp. Physiol. 89, 407-416 http://dx.doi.org/10.1113/expphysiol.2004.027482

Golomb E., Abassi Z. A., Cuda G., Stylianou M., Panchal V. R., Trachewsky D., Keiser H. R. (1994): Angiotensin II maintains, but does not mediate, isoproterenol-induced cardiac hypertrophy in rats. Am. J. Physiol. 267, H1496-1506

Gomez A. M., Guatimosim S., Dilly K. W., Vassort G., Lederer W. J. (2001): Heart failure after myocardial infarction: altered excitation-contraction coupling. Circulation 104, 688-693 http://dx.doi.org/10.1161/hc3201.092285

Grimm D., Elsner D., Schunkert H., Pfeifer M., Griese M., Bruckschlegel G., Muders F., Riegger G. A. J., Kromer E. P. (1998): Development of heart failure following isoproterenol administration in the rat: role of the renin - angiotensin system. Cardiovasc. Res. 37, 91-100 http://dx.doi.org/10.1016/S0008-6363(97)00212-5

Haunstetter A., Izumo S. (2000): Toward antiapoptosis as a new treatment modality. Circ. Res. 86, 371-376

Heijman J., Volders P. G., Westra R. L., Rudy Y. (2011): Local control of $\beta$-adrenergic stimulation: Effects on ventricular myocyte electrophysiology and $\mathrm{Ca}(2+)$-transient. J. Mol. Cell. Cardiol. 50, 863-871 http://dx.doi.org/10.1016/j.yjmcc.2011.02.007

Horiuchi-Hirose M., Kashihara T., Nakada T., Kurebayashi N., Shimojo H., Shibazaki T., Sheng X., Yano S., Hirose M., Hongo M., Sakurai T., Moriizumi T., Ueda H., Yamada M. (2010): Decrease in the density of t-tubular L-type Ca2+ channel currents in failing ventricular myocytes. Am. J. Physiol. 300, 978-988

Houser S. R. (2001): Reduced abundance of transverse tubules and L-type calcium channels: another cause of defective contractility in failing ventricular myocytes. Cardiovasc. Res. 49, 253-256 http://dx.doi.org/10.1016/S0008-6363(00)00305-9

Kahn D. S., Rona G., Chappel C. I. (1969): Isoproterenol-induced cardiac necrosis. Ann. NY. Acad. Sci. 156, 285-293 http://dx.doi.org/10.1111/j.1749-6632.1969.tb16735.x

Kannel W. B. (1998): Epidemiology of cardiac hypertrophy. In: Left Ventricular Hypertrophy. (Ed. D. J. Sheridan), pp. 1-10, Churchill Livingstone, London

Khan M. G. (2003): ECG and its evaluation. Grada, Prague, 340 (in Czech)

Korb G., Totovič V. (1967): Elektronmikroskopische untersuchungen über fruhvenderungen im zentrum und in der peripherie experimenteller herzinfarkte. Virch. Arch. Anat. 342, 85-96 http://dx.doi.org/10.1007/BF00956851
Králová E., Mokráň T., Murín J., Stankovičová T. (2008): Electrocardiography in two models of isoproterenol-induced left ventricular remodeling. Physiol. Res. 57, 83-89

Králová E., Mikušová A., Novotová M., Stankovičová T. (2009): Myocardial remodeling induced by repeated doses of isoproterenol. Physiol. Res. 58, P14

Křenek P., Klimas J., Kroslakova M., Gazova A., Plandorova J., Kucerova D., Fecenkova A., Svec P., Kyselovic J. (2006): Increased expression of endothelial nitric oxide synthase and caveolin-1 in the aorta of rats with isoproterenol-induced cardiac hypertrophy. Can. J. Physiol. Pharmacol. 84, 1245-1250 http://dx.doi.org/10.1139/y06-073

Křenek P., Kmecova J., Kucerova D., Bajuszova Z., Musil P., Gazova A., Ochodnicky P., Klimas J., Kyselovic J. (2009): Isoproterenolinduced heart failure in the rat is associated with nitric oxidedependent functional alterations of cardiac function. Eur. J. Heart Fail. 11, 140-146 http://dx.doi.org/10.1093/eurjhf/hfn026

Landmesser U., Drexler H. (2007): Update on inotropic therapy in the management of acute heart failure. Curr. Treat. Options Cardiovasc. Med. 9, 443-449 http://dx.doi.org/10.1007/s11936-007-0039-9

Leenen F. H., White R., Yuan B. (2001): Isoproterenol-induced cardiac hypertrophy: role of circulatory versus cardiac reninangiotensin system. Am. J. Physiol. 281, H2410-2416

Lijnen P. J., Petrov V. V., Fagard R. H. (2000): Induction of cardiac fibrosis by angiotensin II. Methods Find. Exp. Clin. Pharmacol. 22, 709-723 http://dx.doi.org/10.1358/mf.2000.22.10.802287

Limbird L. E., Voughan D. E. (1999): Augmenting beta receptors hastens relaxation and mediates phosphorylation in the heart: short-term gains offset by long-term of phospholamban, troponin I, and C-protein in pains? Proc. Natl. Acad. Sci. U.S.A. 96, 7125-7127 http://dx.doi.org/10.1073/pnas.96.13.7125

Linck B., Bokník P., Baba H. A., Eschenhagen T., Haverkamp U., Jäckel E., Jones L. R., Kirchhefer U., Knapp J., Läer S., Müller F. U., Schmitz W., Scholz H., Syska A., Vahlensieck U., Neumann J. (1998): Long-term beta adrenoceptor-mediated alteration in contractility and expression of phospholamban and sarcoplasmic reticulum $\mathrm{Ca} 2+$-ATPase in mammalian ventricle. J. Pharmacol. Exp. Ther. 286, 531-538

López-López J. R., Shacklock P. S., Balke C. W., Wier W. G. (1995): Local calcium transients triggered by single L-type calcium channel currents in cardiac cells. Science 268, 1042-1045 http://dx.doi.org/10.1126/science.7754383

Ma X., Song Y., Chen C., Fu Y., Shen Q., Li Z., Zhang Y. (2011): Distinct actions of intermittent and sustained $\beta$-adrenergic receptor stimulation on cardiac remodeling. Sci. China Life Sci. 54, 493-501 http://dx.doi.org/10.1007/s11427-011-4183-9

Mathew J., Sleight P., Lonn E., Johnstone D., Pogue J., Yi Q., Bosch J., Sussex B., Probstfield J., Yusuf S., Heart Outcomes Prevention Evaluation (HOPE) Investigators (2001): Reduction of cardiovascular risk by regression of electrocardiographic markers of left ventricular hypertrophy by the angiotensin-converting enzyme inhibitor ramipril. Circulation 104, 1615-1621 http://dx.doi.org/10.1161/hc3901.096700 
Mészáros J., Khananshvili D., Hart G. (2001): Mechanisms underlying delayed afterdepolarizations in hypertrophied left ventricular myocytes of rats. Am. J. Physiol. 281, 903-914

Mészáros J., Levai G. (1990): Ultrastructural and electrophysiological alterations during the development od catecholamine-induced cardiac hypertrophy and failure. Acta Biol. Hung. 41, 289-307

Mészáros J., Pasztor B. (1995): Effect of ouabain in catecholamineinduced cardiac hypertrophy. Acta Physiol. Hung. 1, 55-62

Mikušová A., Králová E., Tylková L., Novotová M., Stankovičová T. (2009): Myocardial remodeling induced by repeated low doses of isoproterenol. Can. J. Physiol. Pharmacol. 87, 641-651 http://dx.doi.org/10.1139/Y09-053

Moalic J. M., Charlemagne D., Mansier P., Chevalier B., Swynghedauw B. (1993a): Cardiac hypertrophy and failure--a disease of adaptation. Modifications in membrane proteins provide a molecular basis for arrhythmogenicity. Circulation 87, IV21-26

Moalic J. M., Bourgeois F., Mansier P., Machida C. A., Carré F., Chevalier B., Pitarque P., Swynghedauw B. (1993b): Beta 1 adrenergic receptor and $G$ alpha $s$ mRNAs in rat heart as a function of mechanical load and thyroxine intoxication. Cardiovasc. Res. 27, 231-237 http://dx.doi.org/10.1093/cvr/27.2.231

Nagano M., Higaki J., Nakamura F., Higashimori K., Nagano N., Mikami H., Ogihara T. (1992): Role of cardiac angiotensin II in isoproterenol induced left ventricular hypertrophy. Hypertension $19,708-712$

Nichtová Z., Králová E., Novotová M., Stankovičová T. (2010): Ultrastructural and functional myocardial changes induced by 3 weeks lasting addition of low doses of isoproterenol to rats. Physiol. Res. 59, 26P

Novotová M., Tylková L., Zahradník I., Zahradníková A. (2006): Ultrastructural changes in cardiac cells after a single application of isoproterenol. New Frontiers in Basic Cardiovascular Research. Debrecen, Hungary 5-8 Oct. Program and abstracts L13, 35

Ocaranza M. P., Diaz-Araya G., Chiong M., Munoz D., Riveros J. P., Ebensperger R., Sabat S., Irarrázaval P., Jalil J. E., Lavandero S. (2002): Isoproterenol and angiotensin I-converting enzyme in lung, left ventricle and plasma during myocardial hypertrophy and fibrosis. J. Cardiovasc. Pharmacol. 40, 246-254 http://dx.doi.org/10.1097/00005344-200208000-00010

Oikarinen L., Nieminen M.S., Viitasalo M., Toivonen L., Jern S., Dahlof B., Devereux R. B., Okin P. M., Life study investigators (2004): QRS duration and QT interval predict mortality in hypertensive patients with left ventricular hypertrophy: Losartan intervention for endpoint reduction in hypertension study. Hypertension 43, 1029-1034 http://dx.doi.org/10.1161/01.HYP.0000125230.46080.c6

Okin P. M., Devereux R. B., Jern S., Kjeldsen S. E., Julius S., Nieminen M. S., Snapinn S., Harris K. E., Aurup P., Edelman J. M., Dahlof B. (2003): Regression of electrocardiographic left ventricular hypertrophy by losartan versus atenolol: the losartan intervention for endpoint reduction in hypertension (life) study. Circulation 108, 684-690 http://dx.doi.org/10.1161/01.CIR.0000083724.28630.C3

Okin P. M., Nieminen M. S., Jern S., Oikarinen L., Viitasalo M., Toivonen L., Kjeldsen S. E., Julius S., Snapinn S., Dahlof B.
(2004): Electrocardiographic strain pattern and prediction of cardiovascular morbidity and mortality in hypertensive patients. Hypertension 44, 48-54 http://dx.doi.org/10.1161/01.HYP.0000132556.91792.

Osadchii O. E. (2007): Cardiac hypertrophy induced by sustained $\beta$-adrenergic receptor activation: pathophysiological aspects. Heart Fail. Rev. 12, 66-86 http://dx.doi.org/10.1007/s10741-007-9007-4

Ozaki M., Kawashima S., Yamashita T., Hirase T., Ohashi Y., Inoue N., Hirata K., Yokoyoma M. (2002): Overexpression of endothelial nitric oxide synthase attenuates cardiac hypertrophy induced by chronic isoproterenol infusion. Circulation 66, 851-856

http://dx.doi.org/10.1253/circj.66.851

Pick R., Jalil J. E., Janicki J. S., Weber K. T. (1989): The fibrillar nature and structure of isoproterenol-induced myocardial fibrosis in the rat. Am. J. Pathol. 134, 365-371

Poupa O. (1962): On physiological adaptations. Cas. Lek. Cesk. 101, 776-781 (in Czech)

Raab W. (1960): Key position of catecholamines in functional and degenerative cardiovascular pathology. Am. J. Cardiol. $5,571-578$ http://dx.doi.org/10.1016/0002-9149(60)90121-1

Rajadurai M., Prince P. S. (2007): Preventive effect of narginin on cardiac mitochondrial enzymes during isoproterenol-induced myocardial infarction in rats: a transmission electron microscopic study. J. Biochem. Mol. Toxicol. 21, 354-361 http://dx.doi.org/10.1002/jbt.20203

Ribeiro D. A., Buttros J. B., Oshima C. T. F., Bergamaschi C. T., Campos R. R. (2009): Ascorbic acid prevents acute myocardial infarction induced by isoproterenol in rats: role of inducible nitric oxide synthase production. J. Mol. Hist. 40, 99-105 http://dx.doi.org/10.1007/s10735-009-9218-1

Rona G., Chappel C. I., Balazs T., Gaudry R. (1959): An infarct-like myocardial lesion and other toxic manifestations produced by isoproterenol in the rat. AMA Arch. Path. 67, 443-455

Rona G., Kahn D. S., Chappel C. I. (1961): Study on the healing of cardiac necrosis in the rat. Am. J. Pathol. 39, 473-489

Rona G. (1985): Catecholamine cardiotoxicity. J. Mol. Cell. Cardiol. $17,291-300$ http://dx.doi.org/10.1016/S0022-2828(85)80130-9

Sethi R., Saini H. K., Guo X., Wang X., Elimban V., Dhalla N. S. (2007): Dependence of changes in beta-adrenoceptor signal transduction on type and stage of cardiac hypertrophy. J. Appl. Physiol. 102, 978-984 http://dx.doi.org/10.1152/japplphysiol.00921.2006

Sia Y. T., Parker T. G., Tsoporis J. N., Liu P., Adam A., Rouleau J. L. (2002): Long-term effects of carvedilol on left ventricular function, remodeling, and expression of cardiac cytokines after large myocardial infarction in the rat. J. Cardiovasc. Pharmacol. 39, 73-87 http://dx.doi.org/10.1097/00005344-200201000-00009

Soltysinska E., Thiele S., Olesen S. P., Osadchii O. E. (2011a): Chronic sympathetic activation promotes downregulation of $\beta$-adrenoceptor-mediated effects in the guinea pig heart independently of structural remodeling and systolic dysfunction. Pflügers Arch. 462, 529-543 http://dx.doi.org/10.1007/s00424-011-1005-7 
Soltysinska E., Olesen S. P., Osadchii O. E. (2011b): Myocardial structural, contractile and electrophysiological changes in the guinea-pig heart failure model induced by chronic sympathetic activation. Exp. Physiol. 96, 647-663 http://dx.doi.org/10.1113/expphysiol.2011.058503

Song L. S., Sobie E. A., McCulle S., Lederer W. J., Balke C. W., Cheng H. (2006): Orphaned ryanodine receptors in the failing heart. Proc. Natl. Acad. Sci. U.S.A. 103, 4305-4310 http://dx.doi.org/10.1073/pnas.0509324103

Strand A. H., Gudmundsdottir H., Os I., Smith G., Westheim A. S., Bjørnerheim R., Kjeldsen S. E. (2006): Arterial plasma noradrenaline predicts left ventricular mass independently of blood pressure and body build in men who develop hypertension over 20 years. J. Hypertens. 24, 905-913 http://dx.doi.org/10.1097/01.hjh.0000222761.07477.7b

Suzuki M., Ohte M., Wang Z-M., Williams Jr. D. L., Little W. C., Cheng Ch.- P. (1998): Altered inotropic response of endothelin-1 in cardiomyocytes from rats with isoproterenol-induced cardiomyopathy. Cardiovasc. Res. 39, 589-595 http://dx.doi.org/10.1016/S0008-6363(98)00166-7

Swynghedauw B. (2005): The acquired long QT during cardiac hypertrophy. Origin, incidence and significance. Bull. Acad. Natl. Med. 1, 31-40

Tang Ch., Yang J., Wu L. L., Dong L. W., Liu M. S. (1998). Phosphorylation of $\beta$-adrenergic receptor leads to its redistribution in rat heart during sepsis. Am. J. Physiol. 274, R1078-1086

Tang M., Zhang X., Li Y., Guan Y., Ai X.,Szeto C., Nakayama H., Zhang H., Ge S., Molkentin J. D., Houser S. R., Chen X. (2010): Enhanced basal contractility but reduced excitation-contraction coupling efficiency and beta-adrenergic reserve of hearts with increased Cav1.2 activity. Am. J. Physiol. Heart. Circ. Physiol. 299, H519-528 http://dx.doi.org/10.1152/ajpheart.00265.2010

Tang Q., Taylor P. B. (1984): Regression of isoproterenol-induced cardiac hypertrophy. Can. J. Physiol. Pharmacol. 62, 1141-1146 http://dx.doi.org/10.1139/y84-191
Teerlink J. R., Pfeffer J. M., Pfeffer M. A. (1994): Progressive ventricular remodeling in response to diffuse isoproterenol-induced myocardial necrosis in rats. Circ. Res. 75, 105-113

Turek Z., Kalus M., Poupa O. (1966): The effect of isoprenaline pretreatment on the size of acute myocardial necrosis induced by the same drug. Physiol. Bohemoslov. 15, 353

Verdecchia P., Schillaci G., Borgioni C., Ciucci A., Gattobigio R., Zampi I., Reboldi G., Porcellati C. (1998): Prognostic significance of serial changes in left ventricular mass in essential hypertension. Circulation 97, 48-54

Zhang G. X., Kimura S., Nishiyama A., Shokoji T., Rahman M., Yao L., Nagai Y., Fujisawa Y., Miyatake A., Abe Y. (2005): Cardiac oxidative stress in acute and chronic isoproterenol-infused rats. Cardiovasc. Res. 65, 230-238 http://dx.doi.org/10.1016/j.cardiores.2004.08.013

Zhang Y., Li Y., Liu B., Wei R., Wang D., Tan X., Bu D., Pang Y., Tang C. (2007): Urotensin II accelerates cardiac fibrosis and hypertrophy of rats induced by isoproterenol. Acta Pharmacol. Sin. 28, 36-43 http://dx.doi.org/10.1111/j.1745-7254.2007.00485.x

Zierhut W., Zimmer H. G. (1989): Significance of myocardial alpha- and beta-adrenoceptors in catecholamine-induced cardiac hypertrophy. Circ. Res. 65, 1417-1425

Zimmer H. G. (1997): Catecholamine-induced cardiac hypertrophy: significance of proto-oncogene expression. J. Mol. Med. $75,849-859$ http://dx.doi.org/10.1007/s001090050176

Zou Y., Komuro I., Yamazaki T., Kudoh S., Uozumi H., Kadowaki T., Yazaki Y. (1999): Both Gs and Gi proteins are critically involved in isoproterenol-induced cardiomyocyte hypertrophy. J. Biol. Chem. 274, 9760-9770 http://dx.doi.org/10.1074/jbc.274.14.9760

Received: October 18, 2011

Final version accepted: January 16, 2012 